УДК: 351

DOI: https://doi.org/10.32689/2618-0065-2020-1(3)-140-152

Мурашко Віталій Сергійович, старший викладач кафедри публічного адміністрування, аспірант, Міжрегіональна Академія управління персоналом, 03039, м. Київ, вул. Фрометівська, 2, тел.: 06349531 43, e-mail: murashko.vitalii1981@gmail.com.

ORCID: 0000-0002-8668-2043

\title{
СУЧАСНІ ПРОЦЕСИ ТРАНСФОРМАЦІЇ ВИКЛИКІВ ТА ЗАГРОЗ НАЦІОНАЛЬНІЙ БЕЗПЕЦІ КРАЇН-ЧЛЕНІВ СС
}

Анотація: Обгрунтовано, що, сьогодні, цивільні та військові аналітики зацікавлені в тому, щоб здобути сучасні знання 3 питань трансформації викликів та загроз національній безпеці країн-членів СС, при чому не лише 3 питань військової й державної безпек, а й практично безпеки всіх сфер людської життєдіяльності. Визначено, що Свропейський Союз, на відміну від Північноатлантичного альянсу, не $\epsilon$ військово-політичною організацією і ніколи не мав наміру стати нею, але, з самого початку свого існування, держави-члени Європейського Союзу усвідомлювали наскільки важливим елементом соціально-економічних і політичних відносин $є$ безпека для процвітання та свободи демократичного суспільства, економічної інтернаціоналізації, розвитку науки, медицини, промисловості.

Зазначено на особливій небезпеці гібридних війн, що полягає у тому, що ворог поводить себе надзвичайно хитро та підступно, роблячи часто себе другом. Тому, у сучасному світі руйнівні наслідки гібридної війни не можна не дооцінювати, що саме по собі, також, є викликом сучасній демократії, збереженню суверенітету держави та розвитку громадянського суспільства.

Доведено, що особлива увага у Європейському Союзі, також, приділяється розвитку можливостей швидкого реагування на екологічні та енергетичні проблеми, кіберзлочинність, посилення міжетнічних, міжконфесійних та інших конфліктів шляхом усунення процедурних, фінансових та політичних факторів, що перешкоджають розгортанню бойових дій, ускладнюють формування військ та знижують ефективність військових операцій у рамках спільної політики безпеки та оборони.

Профілактику виникненню конфліктам пропонується реалізовувати шляхом розробки, адекватного сучасним реаліям, механізму раннього виявлення загроз європейській системі безпеки для своєчасного реагування на них. Як показав досвід російської агресії проти України, Європейський Союз, тривалий час, не отримував належних сигналів від Києва про загрозу європейській безпеці, що надходить зі Сходу. Появі такого механізму має передувати формування загального центру збору, аналізу та координації інформації для забезпечення національних пріоритетів розвитку безпеки 
держав. Подібний механізм вже існує в Агенції FRONTEX, але лише на рівні охорони громадського порядку і державного кордону.

Ключові слова: національна безпека, виклики та загрози національній безпеці, державний кордон, кіберзлочинність, посилення міжетнічних, міжконфесійних та інших конфліктів.

Murashko Vitaliy Sergeevich, Senior Lecturer of the Department of Public Administration, Postgraduate, Interregional Academy of Personnel Management, 03039, Kiev, st. Frometovskaya, 2, tel.: 06349531 43, e-mail: murashko.vitalii1981@gmail.com.

ORCID: 0000-0002-8668-2043

\section{CURRENT PROCESSES OF TRANSFORMATION OF CHALLENGES AND THREATS TO THE NATIONAL SECURITY OF EU MEMBER STATES}

Abstract: It is substantiated that, today, civil and military analysts are interested in acquiring up-to-date knowledge on the transformation of challenges and threats to the national security of EU Member States, with not only military and national security issues but also virtually all spheres of human life. It is determined that the European Union, unlike the North Atlantic Alliance, is not a military and political organization and never intended to become one, but from the very beginning of its existence, the Member States of the European Union were aware of how important a component of socio-economic and political relations is. security for the prosperity and freedom of a democratic society, economic internationalization, the development of science, medicine, industry.

There is a particular danger of hybrid wars, which is that the enemy behaves extremely cunningly and cunningly, often making himself a friend. Therefore, in today's world, the devastating effects of hybrid warfare cannot be overstated, which in itself is also a challenge to modern democracy, the preservation of state sovereignty and the development of civil society.

It is proved that special attention in the European Union is also paid to the development of rapid response to environmental and energy problems, cybercrime, intensification of interethnic, interfaith and other conflicts by eliminating procedural, financial and political factors that hamper the deployment of fighting, reduce the effectiveness of military operations under a common security and defense policy.

Conflict prevention is proposed to be implemented through the development of a mechanism for early detection of threats to the European security system in order to respond to modern realities. As the experience of Russian aggression against Ukraine has shown, the European Union, for a long time, did not receive proper signals from Kiev about the threat to European security coming from the East. The emergence of such a mechanism should be preceded by the formation of 
a common center for the collection, analysis and coordination of information to ensure national priorities for the development of the security of states. A similar mechanism already exists in the FRONTEX Agency, but only at the level of public order and the state border.

Keywords: national security, challenges and threats to national security, state border, cybercrime, intensification of interethnic, interfaith and other conflicts.

Постановка проблеми. Сьогодні, Свропейський Союз є потужним «гравцем» на арені міжнародної політики, що $є$ одним 3 найпомітніших феноменів світового розвитку. Одним із найважливіших напрямів співробітництва між країнами Свропейського Союзу є створення спільної зовнішньої та безпекової політик, які спрямовані на вирішення військових конфліктів та досягнення взаєморозуміння між ворогуючими сторонами [1, с. 30].

Європейська система безпеки i оборони зіткнулася 3 новими небезпечними викликами, які загрожують їй як ззовні, у вигляді агресивних дій однієї сторони проти іншої, так і із середини - прояви тероризму, радикалізму, масштабні насильницькі дії, нелегальна міграція тощо. Поширення терористичних проявів та масштабність їхніх руйнівних наслідків в Свропі змусили ключові міжнародні організації у європейському просторі - Свропейський Союз, Північноатлантичний альянс і Організацію 3 безпеки i співробітництва в Європі переосмислити свої підходи до забезпечення безпеки та стабільності, що, в свою чергу, актуалізувало проблеми національної безпеки у міжнародному масштабі [2].

За останні роки, з’явилося багато нових публікацій з питань розвитку європейської політики у галузі безпеки і оборони, в контексті процесів глобалізації в їх тісному взаємозв'язку.

Однак, цивільні та військові аналітики зацікавлені в тому, щоб здобути сучасні знання 3 даного питання, при чому не лише з питань військової й державної безпек, а й практично безпеки всіх сфер людської життєдіяльності. Європейський Союз, на відміну від Північноатлантичного альянсу, не є військово-політичною організацією і ніколи не мав наміру стати нею, але, 3 самого початку свого існування, держави-члени Свропейського Союзу усвідомлювали наскільки важливим елементом соціально-економічних i політичних відносин $є$ безпека для процвітання та свободи демократичного суспільства, економічної інтернаціоналізації, розвитку науки, медицини, промисловості.

Аналіз останніх досліджень та публікацій. Серед експертів, дослідження яких висвітлюють питання інституту національної держави, суверенітету й національної безпеки країн-членів СС, можна відзначити таких науковців, як: Б. Бальцерович [3], Р. Кужняр [4], А. Мартинов [5], I. Резстак [6], С. Фоменко [7], В. Шатун [8]. На основі опрацювання праць зазначених вчених на цю тему, можна резюмувати, що більшість із них 
недостатньо висвітлюють питання фактичної парадигми розвитку системи державно-правового регулювання у сфері безпеки та оборони у Європейському Союзі, у контексті формування архітектури сучасної системи забезпечення європейської безпеки.

Здебільшого, вчені приділяють пильну увагу регуляторним аспектам здійснення спільної європейської політики у галузі безпеки та оборони [9, с.31]. 3 огляду на викладене, було б доцільно розглянути деякі теоретикометодологічні підходи до аналізу процесу трансформації викликів та загроз національній безпеці держав-членів СС, що наповнюється новим змістом, адже змінюється їх парадигма.

Мета статті. Метою цієї статті є розкриття особливостей процесів трансформації викликів та загроз національній безпеці країн-членів СС.

Виклад основного матеріалу. Трансформація - це складний процес, який характеризує зміни, що відбуваються у політичній, економічній, соціальній, правовій, культурній та інших сферах сучасних держав. Важливою особливістю процесу трансформації $\epsilon$ його результат, який відображається у структурному перетворенні систем різного масштабу, глибини, спрямованості, спричиненою внутрішніми, або зовнішніми, факторами, у різних типах демократичних режимів. Тому можна констатувати, що терміном «трансформація» називають лише ті процеси, які пов’язані зі структурними та іншими змінами та спричинюють появу принципово нових ознак та елементів об’єкта, що трансформується, а, також, iз впровадженням нових моделей та механізмів, призначених для підвищення ефективності роботи системи, в цілому, та способів їі забезпечення, зокрема.

Трансформація викликів та загроз національній безпеці є складним i багато в чому кризовим процесом. 3 одного боку, вона призводить до серйозних структурних змін у політичній системі, які, у свою чергу, мають як позитивний, так і негативний впливи на систему безпеки як для людини, так i для суспільства й держави, в цілому. 3 іншого боку, така трансформація тісно взаємопов'язана 3 іншими змінами сутності певних явищ, або змінами характеру відносин між іншими суб’єктами безпеки [10, с. 87-88].

Ризики в економічній сфері та посилення євроскептицизму вважаються традиційними для функціонування країн Європейського Союзу. Однак, процес подолання загроз національній безпеці сучасних держав Європейського Союзу, у найближчій та середньостроковій перспективах, супроводжується міграційними проблемами, проблемами гібридного впливу та іншими викликами, які не були настільки актуальними кілька років тому.

Тому, вважаю за доцільне системно проаналізувати ключові поточні i стратегічні виклики та загрози національній безпеці країнам Європейського Союзу, а саме розглянути взаємозалежність економічних, безпекових (гібридність сучасних конфліктів та тероризму), інституційних, соціальних та інших внутрішніх та зовнішніх проблем, які можуть вплинути на ефективне регулювання, запобігання, усунення та ліквідацію зовнішніх і внутрішніх 
загроз по відношенню до тих, чи інших об'єктів безпеки у Європейському Союзі [11, с.20].

Відносини Свропейського Союзу з різними країнами світу, впродовж свого розвитку, набували різного формату. Геополітична ситуація різних організацій та європейська система безпеки значно змінилися, що, в кінцевому підсумку, призвело до нового економічного стану держав та постановки ними стратегічних цілей та завдань [12, с.26].

Цілком очевидно, що Європа, також, зазнає загроз від викликів ії системі безпеки, що потребує вироблення нових стратегій протистояння проблемам, які загрожують національній безпеці в умовах глобалізації. Як писав В. Горбулін у 2017 р., «... уразливість Свропи зумовлена ії цивілізаційною специфікою: вона звикла грати за правилами, іiі позиція завжди відкрита, сформована на основі вільного обміну думками $\mathrm{i}$ на раціональній аргументації. У цьому сила європейської політики, привабливість європейського дому для багатьох народів, у тому числі для українців» [13., c.47].

Однак, зазначу, що на думку В. Горбуліна, в умовах гібридної, тотальної війни, демократичні процедури, плюралізм, чесна політична конкуренція часто стають слабкою ланкою забезпечення стійкості до загроз у сфері національної безпеки та актуалізують необхідність переосмислення питань, що стосуються теоретичних та практичних аспектів національної безпеки.

Небезпека гібридних війн полягає у тому, що ворог поводить себе надзвичайно хитро та підступно, роблячи часто себе другом. «Ви думаєте, що живете у стані миру, дружби і стратегічного партнерства, а проти вас уже ведуться повномасштабні бойові операції. Ви ніколи не можете бути впевнені, що війна скінчилася, жоден мирний договір, чи угоду про припинення вогню, більше не можна приймати за чисту монету. Агресор буде щиро обурюватися, якщо ви чинитимете спротив, але при цьому вестиме проти вас війну на повне знищення... постраждалі від гібридної агресії неготові визнати, що вони стали жертвами гібридної війни. Масштаб гібридної битви починає усвідомлюватися лише тоді, коли таке розуміння приходить» [13, с. 48]. Тому, у сучасному світі руйнівні наслідки гібридної війни не можна не дооцінювати, що саме по собі, також, є викликом сучасній демократії, збереженню суверенітету держави та розвитку громадянського суспільства.

У документі «Перегляд Свропейської політики сусідства», оприлюдненому 18 листопада 2015 р., безпека $\epsilon$ пріоритетом: «новий фокус на безпеці відкриє широкий спектр нових сфер співпраці в рамках Європейської політики сусі́дства» [14].

Однак, цей документ не забезпечує гарантії безпеки сусідніх країн. Задекларована ним політика спрямована на стабілізацію ситуації Свропейського Союзу з країнами з найближчого оточення, що, тим самим, повинно сприяти уникненню загроз, з якими вона стикається. Тому, на мою 
думку, основними напрямами співпраці Європейського Союзу із сусідніми країнами мають бути: запобігання конфліктам, захист кордонів, проведення політики антитероризму, радикалізація та протидія організованій злочинності, пошук балансу між демократією, глобалізацією і безпекою, а, також, виявлення особливостей системи забезпечення безпеки у нових геополітичних реаліях.

Профілактику виникненню конфліктам пропонується реалізовувати шляхом розробки, адекватного сучасним реаліям, механізму раннього виявлення загроз європейській системі безпеки для своєчасного реагування на них. Як показав досвід російської агресії проти України, Європейський Союз, тривалий час, не отримував належних сигналів від Києва про загрозу європейській безпеці, що надходить зі Сходу. Появі такого механізму має передувати формування загального центру збору, аналізу та координації інформації для забезпечення національних пріоритетів розвитку безпеки держав. Подібний механізм вже існує в Агенції FRONTEX, але лише на рівні охорони громадського порядку і державного кордону.

Важливість своєчасної та ефективної реакцій на виявлену загрозу неодноразово підтверджувалася, починаючи від війни в Грузії у 2008 році до окупації Криму та виникнення нового конфлікту на Донбасі у 2014 році

Щодо політики 3 покращення захисту кордонів країн-партнерів Європейського Союзу, що має убезпечити Євросоюз від потоків мігрантів, контрабанди i наркотрафіків на зовнішніх межах країн-сусідів, не допускаючи їх до кордонів $\mathrm{CC}$, то вона більш-менш зрозуміла. У цьому напрямі, співпраця розвивається досить добре. Наприклад, Державна прикордонна служба України активно співпрацює з Свропейською Агенцією FRONTEX з питань обміну інформацією, спільного аналізу ризиків, участі у спільних операціях, встановлення загального порядку у взаєминах 3 іноземними державами тощо.

24 листопада 2015 року у Брюсселі було підписано угоду, яка передбачає посилене прикордонне співробітництво між Європейським Союзом, Молдовою та Україною, продовження мандату Місії Свропейського Союзу з прикордонної допомоги у Молдові та Україні (EUBAM), а, також, застосування, відповідних для Європейського Союзу, підходів до вирішення прикордонних, митних та податкових питань. Важливість цієї співпраці підкреслюється загрозою Росії використовувати територію Придністров'я для провокаційних та агресивних дій проти України та Молдови.

Для подолання проявів тероризму та радикалізму, Брюссель закликає сусідні країни активізувати свою діяльність у напрямі боротьби 3 їх фінансуванням, a, також, залученням молоді до організації терористичних i радикальних рухів, нелегальною міграцією та торгівлею зброєю через активне включення до співпраці організацій громадянського суспільства та використання сучасних мереж інформаційно-аналітичного та ресурсного 
супроводу національної безпеки, які вже доступні у країнах Свропейського Союзу [2].

Враховуючи нові виклики та загрози, у 2015 р., було розпочато створення Глобальної стратегії зовнішньої політики і безпеки Свропейського Союзу, а вже у 2016 р. був представлений документ під назвою «Спільне бачення, спільні дії: сильніша Свропа» [15; 16].

Глобальна стратегія зовнішньої політики i безпеки Європейського Союзу підкреслює, що у сучасному світі однієї «м'якої» сили недостатньо, необхідно підвищити ефективність Свропейського Союзу у сфері безпеки та оборони. Також, нею визначено основні пріоритети забезпечення безпеки: оборона, антитероризм, кібербезпека, енергетика та стратегічні комунікації [17]. Необхідні передумови для реалізації політики безпеки та оборони Європейського Союзу систематизовані на Рис. 1.

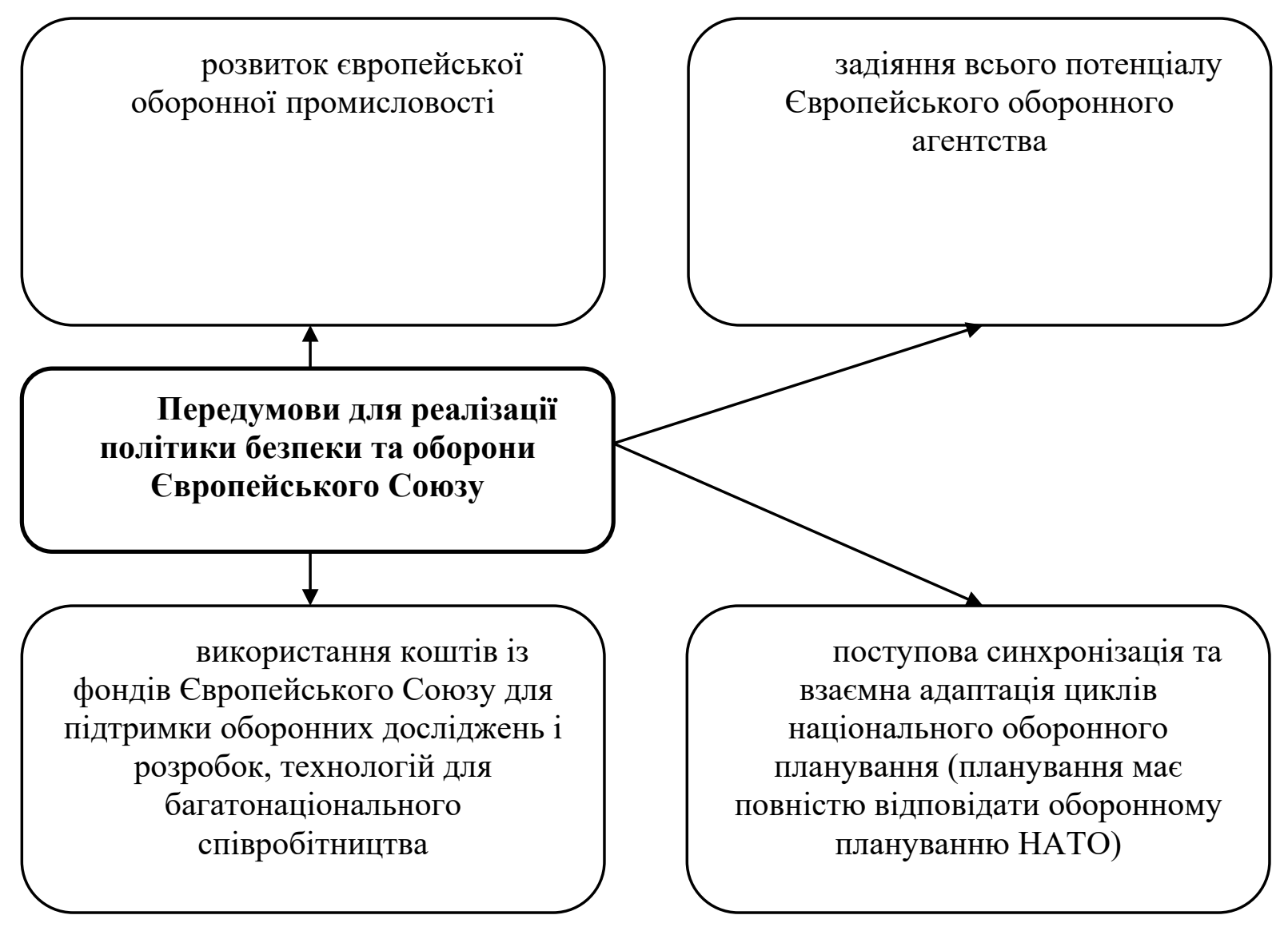

Рис. 1. Передумови для реалізації політики безпеки та оборони Європейського Союзу 
У Глобальній стратегії Європейського Союзу чітко окреслені пріоритети зовнішньополітичних дій Європейського Союзу, які графічно переставлені на Рис. 2.

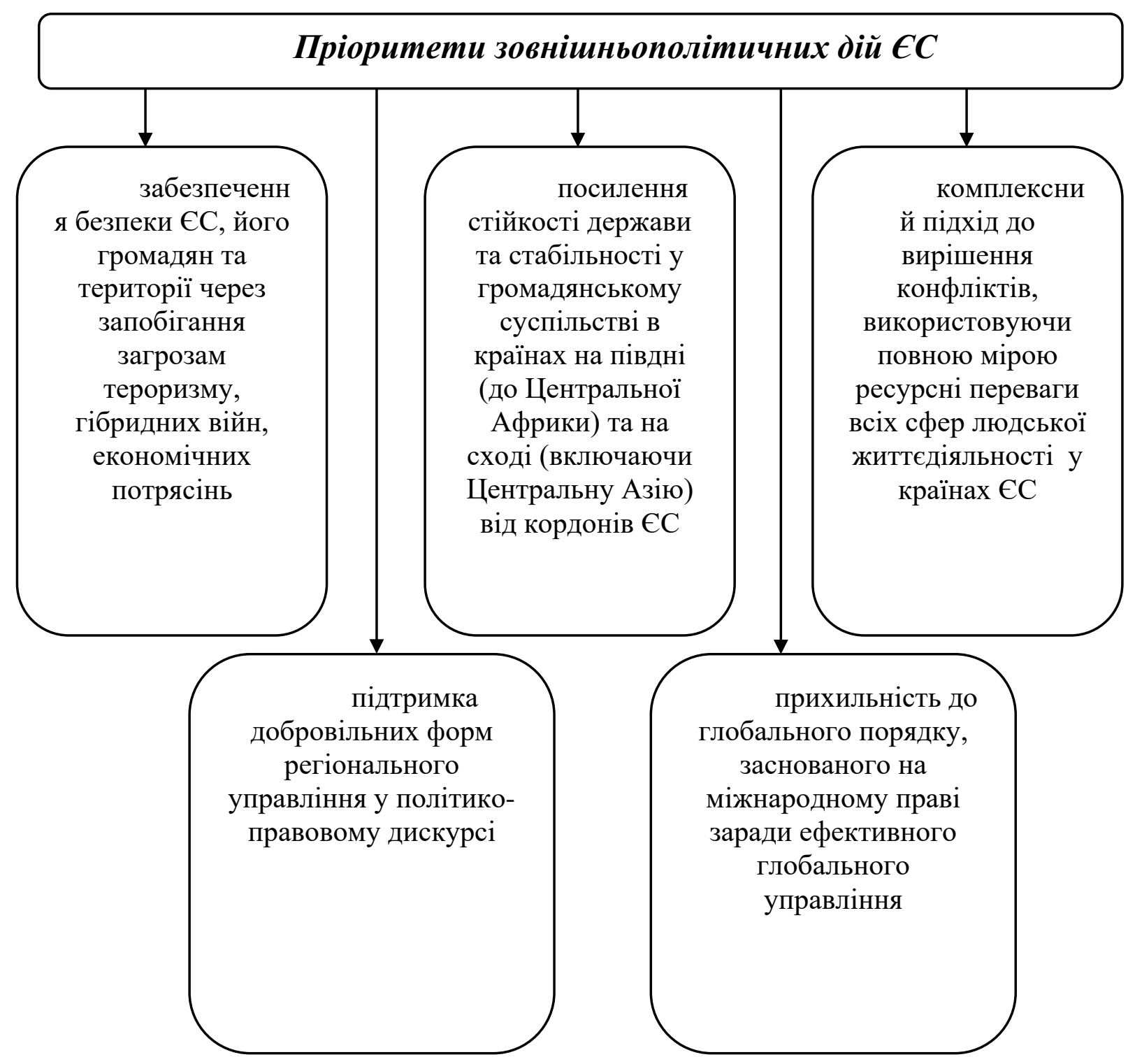

Рис. 2 Пріоритети зовнішньополітичних дій Свропейського Союзу

Глобальна стратегія Європейського Союзу, вперше, визначила, що Європейський Союз має «життєві інтереси», але не має «протиріч між національними та європейськими інтересами». До життєвих інтересів Європейського Союзу належать: безпека громадян Свропейського Союзу та iii територій, добробут населення, демократія, глобальний порядок, 
заснований на правилах для стримування балансу організації влади i розвитку суспільства [18, с. 31].

Глобальна стратегія Європейського Союзу, також, розглядає у якості викликів демографічні показники, міграцію, гібридні загрози та неналежний захист зовнішніх кордонів. Свропейський Союз вважає, що 3 такими загрозами та викликами можна впоратися, в першу чергу, військовими засобами. Разом з тим, вважаю, що потрібна комбінація військових, політичних та економічних засобів в їх тісному взаємозв'язку. При цьому, основна сила Свропейського Союзу пов'язана з його багатим «арсеналом» інструментів забезпечення цивільної безпеки. Дж. Най розуміє це як здатність міжнародних гравців досягати своїх зовнішньополітичних цілей застосуванням засобів, заснованих не на примусі, а на позитивному прагненні, на цінностях, культурі, надійних інституціях та політиці, які міжнародна спільнота визнає законними та достовірними.

Глобальна стратегія Свропейського Союзу поєднує різні зовнішньополітичні погляди всіх держав-членів $Є С$ в єдиному їхньому баченні щодо зовнішніх пріоритетів розвитку Свропейського Союзу і майже усуває розрив між зовнішньою та внутрішньою політиками та безпекою.

Висновки. Отже, резюмуємо, що 3 метою належного реагування на зовнішні небезпеки та забезпечення цілісності Європи, Глобальна стратегія Європейського Союзу декларує те, що Європейський Союз повинен мати всі необхідні сили реагуваня - сухопутний, повітряний, космічний та морський транспорти, включаючи стратегічні ресурси. У зв’язку з цим, слід повністю дотримуватися колективного зобов'язання щодо виділення $20 \%$ від оборонного бюджету держав-членів ЄС на придбання потрібного озброєння та науково-технічний розвиток вітчизняної державно-політичної науки.

Потужна, інноваційна та конкурентоспроможна європейська оборонна промисловість необхідна для забезпечення стратегічної автономії Свропи та проведення надійної спільної політики безпеки та оборони. У Глобальній стратегії Європейського Союзу звертається увага на той факт, що оборонна промисловість може стимулювати економічне зростання та створення нових робочих місць у зв'язку із створенням нових суб'єктів господарювання. Це, безпосередньо, може мати вплив на вирішення сучасних соціальних проблем країн-членів Європейського Союзу. Комплексна європейська оборонна, технологічна та промислова бази вимагають прозорого внутрішнього ринку, a, також, забезпечення участі малих та середніх підприємств у оборонному секторі. Все це, на думку представників Свропейського Союзу, може покращити якість інновацій та інвестицій у військові технології майбутнього.

\section{Лimepamypa:}

1. Труш О. О. Історико-правові засади європейської політики безпеки й оборони / О. О. Труш, Є. М. Нікіпєлова // Теорія та практика державного управління. - 
2016. - Вип. 3. - С. 30-37. - Режим доступу: http://www.kbuapa.kharkov.ua/e-book/tpdu/20163/doc/1/05.pdf

2. Віталій Мартинюк Український незалежний центр Політичних досліджень / ЄВРОПЕЙСЬКА БЕЗПЕКА НА ПОРОЗІ ЗМІН. ВИСНОВКИ ДЛЯ УКРАЇНИ ВИДаННЯ, №16/741,8 грудня $2015 \quad$ року http://www.ucipr.org.ua/index.php?option=com_content\&view=article\&id=57:vropeyskabezpeka-na-poroz-zm-n-visnovki-dlya-ukra-ni\&catid=8\&Itemid=201\&lang=ua

3. Balcerowicz B. (2006), Siły zbrojne w państwie i stosunkach międzynarodowych, Warszawa, p. 99.,

4. Kużnia R. (2005), Polityka i siła, Warszawa, p. 236-237.,

5. Мартинов А. Спільна зовнішня і безпекова політика Європейського Союзу: основні етапи розвитку / А. Мартинов // Свропейські історичні студії. - 2015. - № 1. - С. 43-61. - Режим доступу: http://nbuv.gov.ua/UJRN/eis_2015_1_6

6. Resztak Ilona KONWENCJE RADY EUROPY O PRZECIWDZIALANIU WOBEC ZJAWISKA TERRORYZMU/ Збірник наукових праць Львівського державного університету внутрішніх справ Серія юридична Випуск 2 (1), 2012 http://www.lvduvs.edu.ua/documents_pdf/visnyky/nvsy/01_2012/12ridue.pdf

7. Фоменко С. В. Спільна зовнішня і безпекова політика СС: від національних інтересів до спільних цінностей / С. В. Фоменко // Збірник наукових праць Національної академії державного управління при Президентові України. - 2015. - Вип. 1. - С. 224-242. Режим доступу: http://nbuv.gov.ua/UJRN/znpnadu_2015_1_19

8. Шатун В. Т. Оборонна i безпекова політика Європейського Союзу: формування та еволюція / В. Т. Шатун // Наукові праці [Чорноморського державного університету імені Петра Могили комплексу "Києво-Могилянська академія"]. Сер. : Політологія. - 2014. - Т. 230, Вип. 218. - С. 60-67. - Режим доступу: http://nbuv.gov.ua/UJRN/Npchdupol_2014_230_218_13

9. Юлія Муравська (Якубівська) ПАРАДИГМА РОЗВИТКУ ДЕРЖАВНОПРАВОВОГО РЕГУЛЮВАННЯ ОБОРОНИ І БЕЗПЕКИ В ЄВРОПЕЙСЬКОМУ СОЮЗІ /АКТУАЛЬНІ ПРОБЛЕМИ ПРАВОЗНАВСТВА № 1 (2017), С. 30-35c.31 http://dspace.tneu.edu.ua/bitstream/316497/24503/1/\%D0\%9C\%D1\%83\%D1\%80\%D0\%B0\%D 0\%B2\%D1\%81\%D1\%8C\%D0\%BA\%D0\%B0\%20\%D0\%AE..pdf

10. О. С. Врадій / Вплив політичної трансформації $\mathrm{CC} \mathrm{на} \mathrm{формування}$ стратегічного партнерства 3 іншими акторами міжнародних відносин / О. С. Врадій // Людина, суспільство, політика: актуальні виклики сучасності: матеріали II Міжнародної науково-практичної конференції (м. Одеса, 13-14 лютого 2015 р.) / НУ «ОЮА», Одеське відділення Міжнародної асоціації студентів політологічної науки, за заг. ред. Д. В. Яковлева - Одеса : НУ «ОЮА», 2015. - С. 87-90.

11. Дорош Л.Особливості функціонування та виклики розвитку ЄС у близькій перспективі (2017-2018 pр.) / Л. Дорош, О. Івасечкок // Humanitarian vision. - 2017. - Vol. 3, Num. 1. - C. 19-24.c.20 - Режим доступу: http://science.lpnu.ua/sites/default/files/journalpaper/2017/nov/6650/dorosh.pdf

12. Нікіпєлова Є.М. Генеза державної політики національної безпеки в Україні в контексті формування системи колективної безпеки в Європі. Державне управління та місцеве самоврядування: зб. наук. праць ДРІДУ НАДУ. Вип. 2 (37), 2018. C. 26-34. URL: http://ww.dridu.dp.ua/vidavnictvo/2018/2018_02(37)/6.pdf.

13. Дем'янчук Ю. На шляху до НАТО: сучасні виклики та перспективи реалізації політики безпеки / Ю. Дем'янчук // Вісник Львівського університету. Серія : Міжнародні відносини. - 2019. - Вип. 46. - С. 37-53. С Режим доступу: http://nbuv.gov.ua/UJRN/VLNU_Mv_2019_46_6 
14. EUROPEAN COMMISSION HIGH REPRESENTATIVE OF THE UNION FOR FOREIGN AFFAIRS AND SECURITY POLICY / JOINT COMMUNICATION TO THE EUROPEAN PARLIAMENT, THE COUNCIL, THE EUROPEAN ECONOMIC AND SOCIAL COMMITTEE AND THE COMMITTEE OF THE REGIONS Review of the European

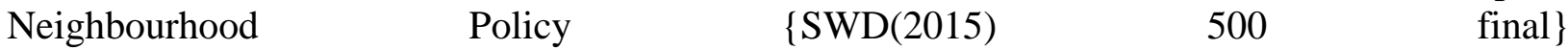
http://eeas.europa.eu/enp/documents/2015/151118_joint-communication_review-of-theenp_en.pdf

15. EU Global Strategy «Shared Vision, Common Action: A Stronger Europe», EUGS http://eeas.europa.eu/archives/docs/top_stories/pdf/eugs_review_web.pdf

16. Капштик О.В. Державні механізми стратегічних комунікацій у секторі безпеки і оборони України. - Дисертація на здобуття наукового ступеня кандидата наук 3 державного управління за спеціальністю 25.00.05 “Державне управління у сфері державної безпеки та охорони громадського порядку”. - Хмельницький університет управління та права, Хмельницький, 2019.С.197

17. Пошедін О. І. Нове життя Спільної політики безпеки та оборони Свропейського Союзу: орієнтири для України / О. І. Пошедін // Вісник Національної академії державного управління при Президентові України. Серія : Державне управління. - 2017. - № 2. - С. 48-54. - Режим доступу: http://nbuv.gov.ua/UJRN/vnaddy_2017_2_9

18. Нікіпєлова Є.М. Генеза державної політики національної безпеки в Україні в контексті формування системи колективної безпеки в Європі. Державне управління та місцеве самоврядування: зб. наук. праць ДРІДУ НАДУ. Вип. 2 (37), 2018. C. 26-34. URL: http://ww.dridu.dp.ua/vidavnictvo/2018/2018_02(37)/6.pdf.

\section{References:}

1. Trush, O.O., Nikipielova, Ye.M. (2016). Istoryko-pravovi zasady yevropeiskoi polityky bezpeky y oborony [Historical and Legal Foundations of European Security and Defense Policy]. Teoriia ta praktyka derzhavnoho upravlinnia - Theory and Practice of Public Administration, 3, 30-37. Retrieved from http://www.kbuapa.kharkov.ua/e-book/tpdu/20163/doc/1/05.pdf [in Ukrainian].

2. Martyniuk, V. (2015). Yevropeiska bezpeka na porozi zmin. Vysnovky dlia ukrainy [European security at the threshold of change. Conclusions for Ukraine]. www.ucipr.org.ua. Retrieved from http://www.ucipr.org.ua/index.php?option=com_content\&view=article\&id=57:vropeyskabezpeka-na-poroz-zm-n-visnovki-dlya-ukra-ni\&catid=8\&Itemid=201\&lang=ua [in Ukrainian].

3. Balcerowicz, B. (2006). Sity zbrojne w państwie i stosunkach międzynarodowych. Warszawa [in Polish].

4. Kużnia, R. (2005). Polityka i siła. Warszawa [in Polish].

5. Martynov, A. (2015). Spilna zovnishnia i bezpekova polityka Yevropeiskoho Soiuzu: osnovni etapy rozvytku [Common Economic and Security Policy of the European Union: Basic Stages of Development]. Yevropeiski istorychni studii - European Historical Studies, 1, 43-61. Retrieved from http://nbuv.gov.ua/UJRN/eis_2015_1_6 [in Ukrainian].

6. Resztak, I. (2012). Konwencje Rady Europy O Przeciwdzialaniu Wobec Zjawiska Terroryzmu. Zbirnyk naukovykh prats Lvivskoho derzhavnoho universytetu vnutrishnikh sprav. Seriia yurydychna - Collection of works of Lviv International Law University. Series: Law, 2(1). Retrieved from http://www.lvduvs.edu.ua/documents_pdf/visnyky/nvsy/01_2012/12ridue.pdf [in Ukrainian].

7. Fomenko, S.V. (2015). Spilna zovnishnia i bezpekova polityka YeS: vid natsionalnykh interesiv do spilnykh tsinnostei [Common economic and security policy of the EU: from national services to common factors]. Zbirnyk naukovykh prats Natsionalnoi akademii derzhavnoho upravlinnia pry Prezydentovi Ukrainy - Collection of works of the National 
Academy of Management under the President of Ukraine, 1, 224-242. Retrieved from http://nbuv.gov.ua/UJRN/znpnadu_2015_1_19 [in Ukrainian].

8. Shatun, V.T. (2014). Oboronna i bezpekova polityka Yevropeiskoho Soiuzu: formuvannia ta evoliutsiia [Defense and Security Policy of the European Union: Leadership and Evolution]. Naukovi pratsi [Chornomorskoho derzhavnoho universytetu imeni Petra Mohyly kompleksu "Kyievo-Mohylianska akademiia"]. Ser. : Politolohiia - Scientific Papers [Peter Mohyla Black Sea University of Kyiv-Mohyla Academy]. Series: Politology, 230(218), 60-67. Retrieved from http://nbuv.gov.ua/UJRN/Npchdupol_2014_230_218_13 [in Ukrainian].

9. Muravska (Yakubivska), Yu. (2017). Paradyhma rozvytku derzhavno-pravovoho rehuliuvannia oborony i bezpeky v yevropeiskomu soiuzi [Paradigm of Development of StateLegal Regulation of Defense and Security in The European Union]. Aktualni problemy pravoznavstva - Actual Problems of Law, 1, 30-35. Retrieved from http://dspace.tneu.edu.ua/bitstream/316497/24503/1/\%D0\%9C\%D1\%83\%D1\%80\%D0\%B0\%D 0\%B2\%D1\%81\%D1\%8C\%D0\%BA\%D0\%B0\%20\%D0\%AE..pdf [in Ukrainian].

10. Vradii, O.S. (2015). Vplyv politychnoi transformatsii YeS na formuvannia stratehichnoho partnerstva z inshymy aktoramy mizhnarodnykh vidnosyn [The Impact of EU Political Transformation on the Formation of Strategic Partnership with Other Actors of International Relations]. D. V. Yakovlev (Eds.). Liudyna, suspilstvo, polityka: aktualni vyklyky suchasnosti - Man, Society, Politics: Current Challenges of the Present: Proceedings of the Second International Scientific and Practical Conference. (pp. 87-90). Odesa: NU «OIuA» [in Ukrainian].

11. Dorosh, L., Ivasechkok, O. (2017). Osoblyvosti funktsionuvannia ta vyklyky rozvytku YeS u blyzkii perspektyvi (2017-2018 rr.) [Features of functioning and challenges of EU development in the near term (2017-2018)]. Humanitarian vision, 3(1), 19-24. Retrieved from http://science.lpnu.ua/sites/default/files/journal-paper/2017/nov/6650/dorosh.pdf [in Ukrainian].

12. Nikipielova, Ye.M. (2018). Heneza derzhavnoi polityky natsionalnoi bezpeky v Ukraini $\mathrm{v}$ konteksti formuvannia systemy kolektyvnoi bezpeky $\mathrm{v}$ Yevropi [The genesis of national security policy in Ukraine in the context of the formation of a collective security system in Europe]. Derzhavne upravlinnia ta mistseve samovriaduvannia - Public administration and local self-government, 2(37), 26-34. Retrieved from http://ww.dridu.dp.ua/vidavnictvo/2018/2018_02(37)/6.pdf [in Ukrainian].

13. Demianchuk, Yu. (2019). Na shliakhu do NATO: suchasni vyklyky ta perspektyvy realizatsii polityky bezpeky [Towards NATO: Current Challenges and Prospects for Security Policy]. Visnyk Lvivskoho universytetu. Seriia : Mizhnarodni vidnosyny - Visnyk of Lviv National University. Series: International Relations, 46, 37-53. Retrieved from http://nbuv.gov.ua/UJRN/VLNU_Mv_2019_46_6 [in Ukrainian].

14. Joint Communication to the European Parliament, the Council, the European Economic and Social Committee and the Committee of the Regions. Review of the European Neighbourhood Policy. \{SWD(2015) 500 final\} (2015). Brussels: European Commission. Retrieved from http://eeas.europa.eu/enp/documents/2015/151118_joint-communication_reviewof-the-enp_en.pdf [in Ukrainian].

15. Shared Vision, Common Action: A Stronger Europe. A Global Strategy for the European Union's Foreign And Security Policy (2016). European Union Global Strategy. eeas.europa.eu. Retrieved from http://eeas.europa.eu/archives/docs/top_stories/pdf/eugs_review_web.pdf [in Ukrainian].

16. Kapshtyk, O.V. (2019). Derzhavni mekhanizmy stratehichnykh komunikatsii u sektori bezpeky i oborony Ukrainy [State mechanisms of strategic communications in the security and defense sector of Ukraine]. Candidate's thesis. Khmelnytskyi: Khmelnytskyi universytet upravlinnia ta prava [in Ukrainian]. 
17. Poshedin, O.I. (2017). Nove zhyttia Spilnoi polityky bezpeky ta oborony Yevropeiskoho Soiuzu: oriientyry dlia Ukrainy [The New Life of the Common Security and Defense Policy of the European Union: Landmarks for Ukraine]. Visnyk Natsionalnoi akademii derzhavnoho upravlinnia pry Prezydentovi Ukrainy. Seriia : Derzhavne upravlinnia - Bulletin of the National Academy of Public Administration under the President of Ukraine. Series: Public Administration, 2, 48-54. Retrieved from http://nbuv.gov.ua/UJRN/vnaddy_2017_2_9 [in Ukrainian].

18. Nikipielova, Ye.M. (2018). Heneza derzhavnoi polityky natsionalnoi bezpeky v Ukraini $\mathrm{v}$ konteksti formuvannia systemy kolektyvnoi bezpeky $\mathrm{v}$ Yevropi [The genesis of national security policy in Ukraine in the context of the formation of a collective security system in Europe]. Derzhavne upravlinnia ta mistseve samovriaduvannia - Public administration and local self-government, 2(37), 26-34. Retrieved from http://ww.dridu.dp.ua/vidavnictvo/2018/2018_02(37)/6.pdf [in Ukrainian]. 